\section{Mortgaging the Earth}

Scott Barrett

Faith and Credit: The World Bank's Secular Empire. By Susan George and Fabrizio Sabelli. Penguin: 1994. Pp. 288. £6.99 (pbk).

I MET recently a developing country's former ambassador to the United Nations. He played a leading role in arguing for a new international economic order in the 1970 s, one that would provide a measure of economic justice in the relations between North and South. "Back then," he told me, "we thought we could change the world." After a moment's hesitation, he added: "What we found is that the world has changed us."

This book chronicles that change, and its authors agree with the ambassador's assessment that the change has been for the worse. If anything, North-South economic divisions have widened over the past two decades. To George and Sabelli, the blame lies with a single organization: the World Bank. They argue their case well. Anyone new to this area will put the book down not only convinced that the World Bank has made a botch of its job, but also angry that the institution has been blind to its errors and that no member government has intervened to change the bank in the light of the evidence of its repeated failures. Yet the case made by the authors reads like the prosecuting attorney's opening remarks at a trial. The novice juror may be convinced, but he or she has heard only one interpretation of a selection of the relevant facts. The experienced juror will know that the defence, if given a chance, will present additional evidence and offer a different interpretation. The defence has no voice in this book, however.

To be fair, I'm not sure that this is a criticism. The World Bank has defended its own case often enough, and if this book can't find any virtue in what the bank has done, then the bank's own publications often fail to find any fault. And the interpretations offered by both are similarly suspect. In Faith and Credit, the bank gets the blame for a vast number of woes, while the bank, in several of its own publications, credits itself with a quantity of successes. My sense is that its record is more mixed, and that it hasn't been as influential - for better or for worse - as either George and Sabelli or the bank itself would have us believe.

The bank was created in 1944 to promote both postwar economic reconstruction and economic development. Over the years, priority in development has been given to poverty reduction, and more recently the bank has assumed the objective of promoting sustainable development. The bank advances these aims by lending money to countries at rates that are lower than these countries could obtain on their own. Increasingly, sectoral loans are conditional on certain policy changes that encourage the opening up of markets. For example, an agricultural sector loan may require that subsidies for fertilizers be reduced. These loans are called structural adjustment loans, and it is these that most irk George and Sabelli.

The authors argue that these loans have been a disaster, and they cite numerous examples. Although the authors do not say so, however, one can also find successes. But what are we to make of these observations? Neither, on its own, is sufficient to tell us whether structural adjustment has failed or succeeded. To know that, one would need to know how all these economies would have performed without structural adjustment, and by definition that is something which we can't observe (although it might be inferred by a careful econometric analysis). Although the authors argue that economies undertaking structural adjustment have not per-
FORGET reindeers - this

is an X-ray image of Pharaoh Ramesses II's nose. The mass of dark specks are grains of peppers, used as a preservative by the embalmers. The bonelike object above the nostril is in fact a plug of solidified resin designed to hold the pepper in place. The picture is reproduced from Mummies: A Journey Through Eternity by Françoise Dunand and Roger Lichtenberg, a compact and ingeniously illustrated guide to these Egyptian antiquities. Thames and Hudson, $£ 6.95$ (pbk). formed well, and that their environments have been degraded in the process, what they do not document is whether these economies and environments would have fared better or even worse without structural adjustment.

More importantly, Faith and Credit does not offer any alternative to the bank's own policies. The closest that the authors get to proposing an alternative is in praising the views of a former World Bank economist, Herman Daly. His views are certainly different from the bank's orthodoxy - its faith - but that doesn't make them better. The bank has been a champion of trade liberalization, whereas Daly believes that countries should seek self-sufficiency. But you and I are not selfsufficient. Why should we believe that countries would be better off if only they didn't trade? Similarly, the view expressed in the book that the bank should assist in financing strategic industrial and trade policies is at best high in risk and at worst pure folly.

Related to this, one might ask why the bank should receive all the blame for the failures of development. Why shouldn't the other development banks and instiutions, the governments of developing countries themselves and academic economists share the blame? The book argues that the regional and bilateral development banks have uncritically embraced the World Bank's own policies, that the governments of developing countries have

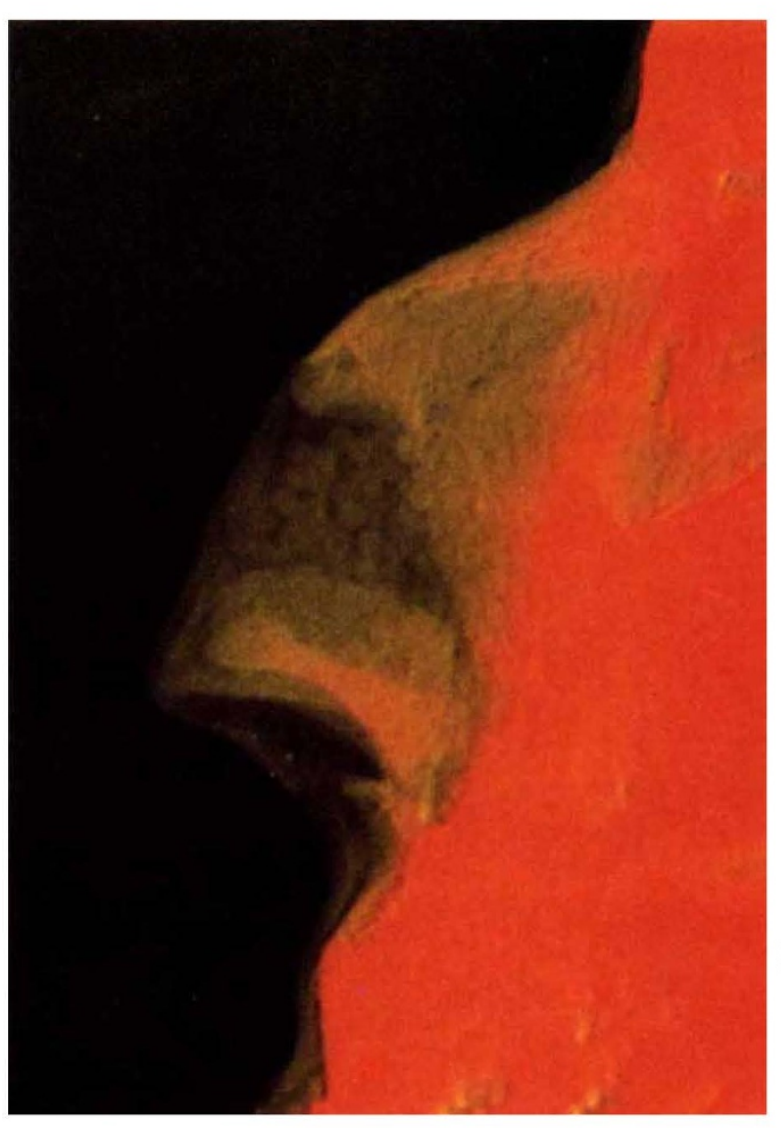

